Religion, Human Rights, Juridification

\title{
Slotte, Pamela Paulina
}

Taylor \& Francis

2019-02-21

Slotte , P P 2019 , Religion, Human Rights, Juridification . in M T Mjaaland (ed.), Formatting of Religion : Across Politics, Education, Media, and Law . Ethics, Human Rights, and Global Political Thought, Taylor \& Francis , New York , pp. 156-174 . https://doi.org/10.4324/9780429030567-10

http://hdl.handle.net/10138/318909

https://doi.org/10.4324/9780429030567-10

acceptedVersion

Downloaded from Helda, University of Helsinki institutional repository.

This is an electronic reprint of the original article.

This reprint may differ from the original in pagination and typographic detail.

Please cite the original version. 
This is an Accepted Manuscript of a book chapter published by Routledge in Formatting Religion: Across Politics, Education, Media, and Law on 21 February 2019 available online: https://www.routledge.com/Formatting-Religion-Across-Politics-Education-Media-and-Law-1stEdition/Mjaaland/p/book/9781138599987

\title{
Religion, Human Rights and Juridification
}

\author{
Pamela Slotte
}

Abstract: The chapter takes a closer look at the tendency to navigate religious diversity by turning to law. It examines how such a turn to law may affect the understanding of and working through of the matters at hand. It offers suggestions for how to critically scrutinise the formatting of religion that takes place through law. While the focus is mainly theoretical, the chapter also explores some tentative proposals with regard to concrete ways of navigating religious diversity.

Keywords: religion, religious diversity, human rights, law, juridification

The aim of this short article is to consider the tendency to navigate religious diversity by turning to law. ${ }^{1}$ The article discusses how such a turn to law may impact the understanding of and working through the matters at hand, and puts forward suggestions for how to critically examine the formatting of religion that takes place through law. The discussion is largely theoretical. However, the article ends by presenting some tentative suggestions as regards concrete ways of navigating religious diversity.

In 2015, the policies of the City of Helsinki, the capital of Finland, caused something of a stir when the city's guidelines regarding the dress-code of the city's employees became well known. The city requires that clothes conform to standards of hygiene and safety and this sets restrictions for persons working in hospitals, kitchens and public parks. But beyond this, there is flexibility and in practice it means that, for example, day-care teachers in city nurseries can wear a niqab, which is a full-body veil that also covers the face apart from the area just around the eyes.

Issues like these relating to the visibility of religious belonging of persons working in the public sector give rise to debates in which we encounter a number of different ways of approaching the matters at hand. Some of the voices are clearly xenophobic. Some, in turn, seem genuinely worried that the niqab will make it difficult for the women wearing it to 
participate in society, thus weakening their position. Some of the responses focus on issues of communication: does the face-veil obstruct the careers in question in their educational tasks or does it not. Some raise concerns of identification and security: what if an unknown person enters the nursery in the guise of the niqab? And some, in turn, question whether or not this breaches the idea of 'neutral' public institutions, an idea which they consider central to any modern democratic state which among its population counts persons who represent a number of different religious and non-religious life-views. The state should not align itself with, privilege or endorse religion in this way. ${ }^{2}$

They find that this attitude and position on part of the state, public authorities and institutions results in equal treatment of all believers and non-believers alike. It is, in fact, an appropriate way to deal with diversity. No one is treated better or worse than the other. Hence, no discrimination, marginalisation or exclusion takes place. This way of thinking has recently found expression, for example, in the 2010 French ban on face coverings. ${ }^{3}$

Now, another way to look at these matters - which still is not as frequent in, for example, the Finnish public discussion, in the sense that I do not see that the terminology would have caught on there in the same way as it has in, for example, Canada or the United Kingdom, is to look at issues like these from the perspective of "reasonable accommodation". As Lori G. Beaman (Beaman, 2012, p. 2), a well-known expert on matters of religious diversity, and religion and law has noted: "[In Canada,] reasonable accommodation as a legal response or principle was originally isolated in employment law as a mechanism of response, by employers to employees' requests for flexibility in relation to their religious practices", be it with regard to dress, observation of holy days or diet, or the like (Beaman, 2012, p. 2). Accommodation was considered appropriate "as long as [it] did not cause the employer undue hardship" (Beaman, 2012, p. 2).

However, the idea of reasonable accommodation has long since freed itself from the context of employment law and instead "emerged as one of the ways within ... [a] multicultural framework" to think about and manage diversity more broadly (Beaman, 2012, p. 5). Reasonable accommodation with regard to a number of different identity markers, signals "the importance that society attaches to protecting", for example, religious freedom and "to showing respect for minorities" (Beaman, 2012, p. 2). Translated into terms of neutrality, what we are dealing with here is a neutrality, which according to a recently finished European funded FP7 project called RELIGARE stands for "inclusive state neutrality" and "justice as evenhandedness". It means that the attitude on part of the state, public institutions and indeed also 
other semi-public actors, should be positive towards religions and other life-views, collaborating with them, and striving to treat them in an equally accommodating manner, paying attention also to their particular needs and interests (Foblets and Alidadi, 2013, pp. 89); (Sorsa, 2015, pp. 49-50).

Now, as many have pointed out, including Beaman herself most forcefully, there necessarily arises here the in no way easy question of where the boundaries should be drawn for what the state has to accommodate: to what extent does it include protection of illiberal positions or even parallel religious legal orders? Is there a danger that we find ourselves on a slippery slope where one boundary after another is pushed through and we risk ending up in a situation with other grave forms of inequality, as the sexual or other non-discrimination rights of some, for example, with regard to reproduction or the choice of one's partner, are sacrificed in favour of the religious rights of others? (Beaman, 2012, p. 6). ${ }^{4}$

Given that schemes of reasonable accommodation rely on some form of articulations of group identity - even if, formally, there would be no need to prove so-called group disadvantage, such as is required in cases of perceived direct or indirect discrimination (Alidadi 2012, pp. 707-708) - is there the risk that we end up cementing traditional conventional social categories instead of affirming the multitude of ways in which individuals and groups in late modern societies negotiate their identities? (Beaman, 2012, p. 7-8). We also have to ask whether reasonable accommodation assigns the ultimate power of interpretation to (religious and cultural) majorities rather than minorities, and in this way essentially preserves the status quo and protects the hegemony of the majority culture (Beaman, 2014, p. 93), ${ }^{5}$ be it in society at large or indeed within various groups?

Despite this poignant criticism, this approach still builds on the important insight that the supposedly secular majority cultures of states, like Finland, for example, despite their best intentions could be faring partly rather poorly when it comes to recognizing religious and nonreligious minority views and concerns, the example of allowing the wearing of the niqab in nurseries in Helsinki being - of course, at least according to some - a positive example to the contrary.

A way to seek to deal with the dilemma of a slippery slope has been to turn to human rights law as a normative framework for equality, non-discrimination and empowerment, and also more generally putting trust in the rule of law and the 'blind' justice of the legal system that they will provide us with models and solutions that secure equal treatment and factual 
equality. Trust is put in law's 'disciplinary' potential. ${ }^{6}$ Human rights is today one of the dominating vocabularies for justice and equality.

Moreover, while not solely a 'legal phenomenon', the last almost 70 years has seen the factual expansion of the human rights legal framework through codifications processes on an international and regional level, the ratification and incorporation of human rights treaties as part of national law, as well as the increasing litigation and case-law that we find, for example, in the European Court of Human Rights, and which is expressive also of the way that people have taken these rights to heart and act on them.

All of this makes human rights part and parcel of a multidimensional phenomenon which scholars have titled juridification. ${ }^{7}$ For reasons of time and space, here I limit myself to saying some words about the way that Lars Blichner and Anders Molander have explicated this concept. According to them, juridification has five dimensions which in various ways may relate to each other. While it is by no means a new phenomenon to regulate life in its various dimensions through law (Loick 2014, p. 762), juridification to them denotes an increase in constitutional amendments and guarantees, such as the establishment of a legal order, rules on separation of powers, competences, individual rights, etcetera, but also constitutive norms in the form of legal doctrines. It also denotes the differentiation and expansion of legal regulation on area after area of human life, as well as the fact that (modern) societies to an increasing extent seek to settle conflicts with the help of law. It further means redistribution and displacement of power, for example, to lawyers, courts and judges. Certain groups are held to be experts and authorities. Lastly, also 'legal framing' forms part of this juridification, meaning that individuals, groups and other entities start to articulate their self-understanding ever more in legal terminology, as 'legal subjects' with individual rights etcetera, in accordance with the articulation of religion, for example, which the legal framework provides, ${ }^{8}$ for purposes of obtaining recognition for their views. Molander and Blichner make clear that there are not necessary causal links between the five dimensions, but that these have to be examined substantially empirically, and can take different shapes (Blichner and Molander 2008, p. 49).

Yet, returning to the matter of a slippery slope, to my mind, and that of many others, things are not this easy, as that we could simply turn to human rights law or indeed general law for solutions. This conclusion follows from what happens to our perception of things when a question or matter is 'juridified', and conceptualised and normatively structured through a legal vernacular. 
For what needs to be pointed out is that law sets forth frames of meaning and shapes our vision of human life and behaviour, including articulating an understanding of, and dealing with, diversity. And alongside other scholars in a critical legal studies-tradition - and, as a scholar indebted also to the insights of the tradition of political theology - I consider legal protection, including that of minorities to be an ambivalent affair. Law does not per definition prevent marginalisation in all its dimensions, nor does it simply 'empower'. Indeed, often enough during the last years, there have been certain recurring issues and themes related to religion that have triggered a call for deeper reflection of seeming paradoxes and ambivalences in contemporary adjudication.

For example, and returning to the case of the niqab, whereas the city of Helsinki has taken a pragmatic stance when it comes to dress codes, the response to this matter on part of the European human rights law would likely be much less benevolent given the way the European Court of Human Rights in its current jurisprudence portrays the matter largely as a conflict of fundamental rights and incommensurable values and has shown insufficient understanding for the viewpoints of veiled women and girls. ${ }^{9}$ I will not look into this case law in more specificity here, nor into the critical observations that have followed in its wake. ${ }^{10}$ But I want to reflect a bit more generally on the reasons for why legal regimes that put forward seemingly neutral standards for equal treatment do not in and off themselves prevent differential treatment in matters of faith in all its dimensions.

The thing is, that law makes sense of some things while downplaying the significance of other things. Beyond addressing disputes that arise and regulating societal life, law is "a species of social imagination" (Rosen, 2006, pp. 8-9, 11-12); (Slotte, 2010, pp. 186-187), a way to conceive of social life. We cannot assume that law would somehow be above and beyond all life. Laws are human products and the interpreters of the law are human institutions with various commitments that affect the kinds of decisions that are made. Someone always has to make the concrete decisions and this is linked to value choices and the subjective assessment of the 'evidence' of the case. As Martti Koskenniemi has put it: "[legal rights have] no meaning independent from the way [they are] interpreted by the relevant authority" (Koskenniemi, 2001, p. 36). For this reason we need to ask, how things are framed, how legal decisions are taken as regards matters of religious accommodation, who makes these decisions and on what basis are they made? We have to study actual situations that are construed, for example, as a legal conflict involving a potential violation of religious freedom, and which we find documented in case law. We have to study the application of the law to understand what the law is taken to mean. 
This is vital, for example, in the case of human rights that are formulated in a very general manner.

I want to combine these observations with the further observation that 'minority' is not necessarily about being numerically inferior, although it importantly can be about that too. The difference between majority and minority is not just quantitative, but as Eliska Pirková has put it in reference to Gilles Deleuze and Félix Guattari: "Majority is rather a constant against which all evaluation is completed and by which all others can be evaluated and allotted to their 'proper' social location." It is about non-dominance (Pirková, 2015, p. 46). Hence, it is also possible that a numerically inferior group can dominate a larger part of the population.

Having the theme of this article in mind, religion and law, this means that we need to critically analyse the kinds of understandings of religion - and indeed other identity markers which guide law when it takes a stand on diversity and the space of freedom that should be afforded individuals and groups, for example, in matters of faith. In which ways does law here contribute to creating and maintaining majority- and minority positions and what are the distributive consequences of this, in Finland and elsewhere? That is, what understandings of religion occupy a dominant position when it comes to law and how does this affect the regulation of religion and management of diversity - to the benefit or detriment of religious minority non-dominant positions.

During the last years, researchers have critically investigated the perceptions of religion that we encounter in national and international law, the limits and emphasis of these perceptions. ${ }^{11}$ For reasons of space, I here simply want to mention some observations that Nathaniel Berman has made regarding human rights law.

Following Berman, human rights law provides us with particular tools for approaching and dealing with matters of religious diversity and freedom in matters of faith. The notion of religion that currently guides human rights institutions is deceptively 'fruitful' when what is seemingly at stake, according to Berman, is the balancing of interests of states and of individuals and of states and of groups. Conflicts stand in focus. It accords to a formalist and likewise pragmatist approach on part of human rights institutions, and international law more generally (Berman, 1995-1996, p. 829-830). Current international legal imagination limits the space of 'absolute' religious freedom to the inner person - where the core of faith resides - and the private space (see e.g. Slotte, 2012 (2010)). This makes the public space a space for legitimate compromise and balancing of 'relative' rights and interests, even though we are here talking about 'human rights'. Formal distinctions and categories considered neutral - in the 
sense that they would cover all belief systems - help human rights institutions to simultaneously seemingly guarantee religious freedom in its most vital aspects, and weigh heavy claims against each other (Berman, 1995-1996, p. 829), as is the case in situations where religious accommodation may or may not be called for.

As Jürgen Habermas has said in another context when describing the ambivalence of the “form of juridification itself" (Blichner and Molander, 2008, p. 50): in order for a "situation to be regulated [through law, it] 'has to be subjected to violent abstraction, not merely because it has to be subsumed under the law, but so that it can be dealt with administratively"' (Blichner and Molander, 2008, p. 50).

Thus what we encounter is an idea of 'religion' that "is both overtly universal and covertly particularist" (Berman, 2012, p. 49), displaying, as the RELIGARE project has phrased this "considerable cultural and religious specificities" in the "legal ordering" (Foblets and Alidadi, 2013 , p. 18), ${ }^{12}$ of religion. Berman calls attention to the contingent nature of formal legal categories and distinctions, asserting that perceiving them as neutral obscures the fact that law functions on the basis of particular ideas about religion and its proper place, and the boundaries that should not be transgressed. Law aspires to "discipline and transmute", 'domesticate' religion, promoting 'good' and counteracting 'bad' religion (Berman, 2012, p. 38, 47).

Building on these observations, we could say that the way the sacred is here being managed, obscures the character of deeply held religious convictions when human rights institutions rephrase these as relative rights-claims, thus ignoring the fact that, as Berman notes, "claims are often enough not articulated" in that language, "but [instead] in the name of", for example, "divine law - the kind of claims that cannot be adjudicated so easily, at least in the modern rights-balancing form of adjudication" (Berman, 1995-1996, p. 829). What this means is that, at the moment, human rights institutions deal with only some aspects of religion. There is exclusion.

What does this example of the results of studies of international human rights law tell us? To put it tentatively: it seems to imply that simple references to the legal framework will not do, when it comes to negotiating diversity and dealing with protection, inclusion and exclusion. A simple faith in law has to be abandoned, if ever it existed. And in the last part of this article, I simply want to suggest a direction in which to proceed from here.

It goes without saying, that any study that seeks to approach issues related to freedom in matters of faith and navigate religious diversity, be it with regard to the potentials here of 
national, regional or international law, will have to map the current religious landscape and identify challenges seemingly related to religious diversity, and problems facing religious minority positions.

Here you need first-hand input from stakeholders. Importantly, as Saba Mahmood has noted in her recent book Religious Difference in A Secular Age: A Minority Report, "even though religious minorities occupy a structurally precarious position in all modern nationstates, the particular shape this inequality takes - its modes of organization and articulation is historically specific. Consequently, the means by which religious minorities wage a struggle against this inequality, as well as the paradoxes and contradictions such struggles generate, vary according to context..." (Mahmood, 2016, p. 11). To this you also have to add a mapping of the current legal framework that addresses religion and seeks to guarantee freedom and equality in matters of faith. This will also importantly include judicial actors applying the law. Just as with the previous observation as regards stakeholders, also here, an in-depth, comprehensive and contextual understanding of the purposes, issues and perspectives that are afforded significance in adjudication processes and decision-making in individual cases is key, so as to - in the words of Jason A. Springs - counteract “excessive discursive analytical tendencies" (Springs, 2016, p. $3){ }^{13}$

Moreover, so as to get a more profound idea of the legal imagination as regards religion and how religious minority positions are constructed and managed, you have to deepen the analysis further. You need to - as I want to call it - 'de-naturalise' and 'de-neutralise' seemingly neutral general legislation and put light on those underlying value assessments and ideas, for example, as regards religion and faith in a broad sense, and the concepts of minority, law itself, statehood and citizenship, that form the basis and direct the application of the law, influencing what is taken as worthy of protection. As said, the contention is, that existing models for responding to and affirming diversity in various ways build on particular views of religion and its relation to and place in society as a whole. ${ }^{14}$ Thus, this more profound analysis of key notions will reveal how, in fact, denoting something as 'religious' authorises specific configurations of power. The framing is political. ${ }^{15}$ This may not be to the detriment of minority religions and other life views and their adherents, but it can be so and contribute to processes of othering.

This strive to understand the logic of today's legal imagination and uncover that which forms silent 'self-evident' presuppositions that structure legal imagination as regards religion, for example, in the area of family law, migration law or employment law, also includes a further step which consists in analysing the historical grammar of these same key concepts and 
categorisations, the claim being, that historical notions affect contemporary legal conceptualisation of religion and that it does so in ways that contribute to unequal treatment of believers. ${ }^{16}$ That is, by studying the historical grammar we reach greater understanding of why the distributive outcomes currently take the form that they do. We catch a glimpse of certain structuring categories, embedded in and expressive of majority culture, which have remained reasonably stable over time.

Thus while processes of juridification affect the perception of the social space and human life, the ways of settling conflicts, and displace other vocabularies and ways of reasoning, it does not necessarily mean a clear cut break with other previously dominant imaginaries anything but.

This, by the way, is a central issue which the project "Protestant Legacies in Nordic Law: Uses of the Past in the Construction of the Secularity of Law" is looking into during 20162019. The Lutheran reformation influenced the institutional context of law, the normative theories about the law, legal concepts and constructions (Research Plan, 2015, pp. 5-6); (Schwarz Lausten, 2011); (Tamm, 2005); (Mäkinen, 2006) and the project builds on the idea that "the Nordic reception of basic Lutheran theological commitments and ideas regarding law (two regiments, three estates and natural law), in conjunction with minority perspectives, [has persisted in] to [the] 21st century, and has paved the way for [among others] a specific interpretation of the secularity of law in the Nordic countries." (Research plan, 2015, p. 5), in the same way as "religious roots in Europe [at large] still play a central but subtle part ... in the identity construction and institutional embedding of norms and values behind the law". (Research plan, 2015, p. 13).

The article in this volume by Lisbet Christoffersen says more about this. For present purposes, I simply want to highlight that the project throughout the 500 years under investigation pays special attention to minority perspectives on Nordic law, and vice versa (Research plan, 2015, p. 5). An overall claim of the project is that we need to thoroughly investigate the extent to which, and how, "past and present theological normativity has influenced [the] understanding of the law of the land" (Research plan, 2015, p. 8) and how the Lutheran heritage and Protestant present may be used or alternatively misused, impacting hereby on the possibility of Nordic countries of preparing for and coping in a good manner with a religiously ever more pluralist future (Research plan, 2015, pp. 8, 13).

An analysis, the steps of which I have sketched out here, and such as is performed in the mentioned project, will help show in a concrete, nuanced and context-sensitive manner, the 
ways in which - and why - law often enough does not live up to our expectations of being able to tend to the needs of all kinds of believers, being instead exclusionary in a way that contradicts the ideals it praises. ${ }^{17}$ Or as the above mentioned project phrases it, we will encounter examples of "tensions" and "the darker sides of majority cultures on law" (Research plan, 2015, p. 5). Summing up, what we strive for and hopefully achieve through these different research steps is to destabilize the relationship of legal institutions, including human rights institutions with the phenomenon of religion. Moreover, we will have put in question the leading liberal idea of legal institutions being about impartial protection of religion, being themselves neutral arbiters outside of the phenomena of the 'sacred'. 18

Returning to Berman, and his observations with regard to international law: the way that religion is approached and handled obscures the character of religious convictions and practices, at least in the sense that at the moment, international and other legal institutions, we may assume, deal with only some aspects of religion. They cannot honestly say that they are including religion in all its variety. However, nor should they think that this would be possible given the indeterminate character of the phenomenon that we are here dealing with.

Moreover, the way that religion is being handled, at least at the level of international law, also obscures the character of the management of the legal (including human rights) institutions itself (Berman, 1995-1996, pp. 830-831). ${ }^{19}$ What is Berman getting at here? What would it mean to follow him on this point?

It is obvious that by taking over jurisdiction in the first place, human rights institutions and other legal institutions already intrude in religious practices in a way that 'insiders' may consider an intrusion and violation. This, however, these institutions must accept. For it is clear that we have to moderate between contradictory claims and competing passions. We have to take a stand and participate in constant redefinition of the socially acceptable forms of the sacred. This is a legitimate task: what do we want to endorse and what do we not want to endorse? ${ }^{20}$ Yet, given that a many-sided analysis of the kind I have sketched out here, will have shown the limits and 'biases' of current legal accounts, the question is in which way solutions can be sought and how minority - non dominant religious positions can be acknowledged in law, in education, in the workplace and the public sphere in general.

For reasons of space, I here simply want to say that, with reference to Berman and other scholars in the critical legal tradition, it could be suggested that we need to re-conceptualize the standard account of the relationship between human rights (and other legal) institutions and religion. Human rights institutions have to conceive themselves as within an undivided sphere 
of the sacred where they participate in a discussion about what is acceptable and desirable. They form part of a dialogue about the boundaries of faith. In this dialogue, one needs to be explicit about the various visions, and quoting Berman: "evaluate them substantively and allow them to compete for our passion with alternative images" (Berman, 1995-1996, p. 831). Here, current human rights institutions are carriers of a certain vision where particular things are held to be fundamental, even 'sacred'. ${ }^{21}$ They can put forward this vision, to which so many all over the world sign up, but also need to self-reflexively and self-critically explore it - and the concrete forms it currently takes - in dialogue with others.

So solutions, be it in a national or an international context, must be sought by giving space to and evaluating substantively different visions of accommodation and equal treatment, among them also the visions put forward by law. ${ }^{22}$

And while taking into consideration the needs, interests and rights of other individuals, groups and society at large, it is important to explicitly give adequate voice to the perspectives of religious minorities as groups and their adherents, and, crucially, also of those persons who find themselves in a religious non-dominant position, without necessarily identifying themselves with any institutionalised religion. As sociologists have pointed out; people today constantly construct and reconstruct their identities, including their religious identities, and perform them in different ways, and while identity is negotiated through dialogue with others, it is not about conforming to models imposed from the outside (Sandberg, 2015, p. 2-3). Instead the subjectivities of each individual has become " $\mathrm{a}$, if not the, unique source of significance, meaning and authority" (Heelas and Woodhead, 2005, p. 3-4, as quoted in Sandberg, 2015, p. 2). This also applies to the rationale for the wearing of symbols like particular forms of dress such as the niqab (Bacquet, 2015). ${ }^{23}$

In fact, the fluid nature of identities has always rendered international jurisdiction difficult, according to Berman in his study of early 20th century legal attempts to deal with religion (Berman, 2012, p. 42). However, this management can be based on more or less explicit self-critical awareness of the purposes for which religious difference is protected, and so forth.

When it comes to providing religious minorities with appropriate conditions for functioning, in Finland and elsewhere, it may be important to look into legislative changes needed, amendments to and reconceptualization of the current legal frameworks. It would seem important, however, to develop context based, practical solutions, with in-built flexibility, that do not end up promoting rigid either/or scenarios - that is, something either is or is not a 
violation - such as are often enough unfortunately favoured by law, or cementing or consolidating identities by leaving no room for the development and change of identities.

Returning to scholars mentioned in this article, somewhat surprisingly perhaps, while the RELIGARE in its summary report of findings, concludes that "the tool of human rights 'allows for diversity only under certain limitations, thereby conditioning and at times even distorting religious experiences"” (Foblets and Alidadi, 2013, p. 13, quoting Alidadi and Foblets, 2012, p. 10) given that the framework for handling, for example, freedom of religion "derives its language and working categories from [Eurocentric] historical and dominant values" (Foblets and Alidadi, 2012, p. 10), they propose that this deficit can be countered by way of "using the important additional tool of legally enshrined reasonable accommodation on the basis of religion and belief" (Foblets et al. 2013, p. 13). It seems counter-intuitive, perhaps, to believe that that legal framework would be any less conditioned, yet the RELIGARE summary report states that "the full potential of these instruments has arguably not been tapped" (Foblets and Alidadi, 2013, p. 13). ${ }^{24}$

Mahmood, in turn, broadens the perspective. She includes in her book on religious difference in a secular age a reflection on "the ideal of religious equality, [and] its significance as a legal mandate versus a human aspiration that characterizes our modern secular imaginary", as she puts it. Her suggestion is "that these two dimensions of religious equality are distinct, neither reducible to the other, and each requiring different kinds of social action. Inasmuch as secularism reduces the ideal of religious equality to a politics of rights and recognition, it privileges the agency of the state, which is far from a neutral arbiter of religious differences. In such a context, [she asks] what social, ethical, and moral resources are available in a secular polity to realize interreligious equality, resources that do not reflect or serve the imperatives of the state" (Mahmood, 2016, p. 28).

In contrast, Beaman, whom I mentioned at the beginning and who associates the language of accommodation closely with the language of law, is critical as regards the fruits, which this union brings. She says that: "The call to manage religious diversity from various sectors has produced a response that has largely been framed in terms of tolerance and accommodation ... [and it has] produced an over-reliance on law and legal solutions and a tendency to look to topdown, or vertical solutions..." (Beaman, 2014, p. 89). Beaman is critical of how law, with its common focus on conflicts frames diversity as a 'negative' matter to be 'dealt with', or 'managed. (Beaman, 2014, p. 90, 92). 
In an attempt to move beyond the problems related to the languages of "reasonable accommodation" and law - echoing hereby the diversified and less stat-centred reflection that Mahmood calls for - Beaman puts forward the notion of "deep equality", by which she means a living, delicate process (Beaman, 2014, p. 96). According to her, we need to focus on the micro level and on how people in their every-day lives successfully navigate diversity and "work out difference" (Beaman, 2014, p. 90). We need to learn from these many micro-level positive examples. Sure enough, in practice people also fail to navigate diversity and they do not always get along with that which is different. This Beaman concedes (Beaman, 2014, p. 92). However, she wants to focus on the positive stories and one of the micro-level examples that she mentions relates to a debate that arose when a picture of two day-care teachers wearing the niqab started to circulated in Québécois media. Some of the parents of the children who these two day-care teachers were taking care of and educating, responded to the commotion by way of an open letter to the media. In this letter, they conceded that they initially had had their misgivings. But above all, they praised the love and excellent care that their children were receiving, and they underscored that the day-care teachers and the parents were united in their dedication to what was in the best interest of the children. They displaced the focus from religious difference to shared views on child rearing (Beaman, 2014, p. 101-102).

\section{References}

Alidadi, K. (2012) 'Reasonable accommodation for religion or belief: Adding value to Art. 9 ECHR and the European Union's anti-discrimination approach to employment?', European Law Review, 37(6), pp. 693-715.

Alidadi, K. and Foblets, M.-C. (2012) 'Framing multicultural challenges in freedom of religion terms: Limitations of minimal human rights for managing religious diversity in Europe', Netherlands Quarterly of Human Rights, 30(4), pp. 388-416.

Årsheim, H. (2015) Lost in Translation? Religion-Making at Four UN Human Rights Committees, 1993-2013. Ph.D. dissertation. Oslo: Akademika.

Årsheim, H. and Slotte, P. (2017) 'The Juridification of Religion?', Brill Research Perspectives in Law and Religion, 1(2), pp. 1-89.

Asad, T. (2003) Formations of the Secular: Christianity, Islam, Modernity. Stanford: Stanford University Press. 
Bacquet, S. (2015) 'Religious Symbols and the Making of Contemporary Religious Identities', in Sandberg, R. (ed.) Religion and Legal Pluralism. Farnham; Burlington: Ashgate, pp. 113-130.

Bader, V. (2007) Secularism or Democracy? Associational Governance of Religious Diversity. Amsterdam: Amsterdam University Press.

Beaman, L. G. (2014) 'Deep Equality as an Alternative to Accommodation and Tolerance', Nordic Journal of Religion and Society, 27(2), pp. 89-111.

Beaman, L. G. (ed.) (2012) Reasonable Accommodation: Managing Religious Diversity. Vancouver; Toronto: UBC Press.

Beaman, L. G. (2012) 'Introduction: Exploring Reasonable Accommodation', in Beaman, L. G. (ed.) Reasonable Accommodation: Managing Religious Diversity. Vancouver; Toronto: UBC Press, pp. 1-12.

Berman, N. (2012) “"The Sacred Conspiracy”: Religion, Nationalism, and the Crisis of Internationalism', Leiden Journal of International Law, 25(1), pp. 9-54.

Berman, N. (1995-1996) 'Legalizing Jerusalem or, of Law, Fantasy, and Faith’, Catholic University Law Review, 45(3), pp. 823-835.

Blichner, L. C. and Molander, A. (2008) 'Mapping Juridification', European Law Journal, 14(1), pp. 36-54.

Brems, E. (ed.) (2014) The Experiences of Face Veil Wearers in Europe and the Law. Cambridge: Cambridge University Press.

Brems, E. et al. (2013) 'Uncovering French and Belgian Face Covering Bans', Journal of Law, Religion and State, 2 (1), pp. 69-99.

Bhuta, N. (2014) 'Two Concepts of Religious Freedom in the European Court of Human Rights', South Asian Quarterly, 113 (1), pp. 9-35.

Cavanaugh, W. T. (2009) The Myth of Religious Violence: Secular Ideology and the Roots of Modern Conflict. Oxford; New York: Oxford University Press.

Christoffersen, L. (2013) 'A Quest for Open Helmets: On the Danish Burqa Affair', in Ferrari, A. and Pastorelli, S. The Burqa Affair Across Europe: Between Public and Private Space. Farnham; Burlington: Ashgate, pp. 171-188. 
Danchin, P. G. (2015) 'Religious Freedom in the Panopticon of Enlightenment Rationality', in Sullivan, W. F. et al. Politics of religious freedom. Chicago; London: University of Chicago Press, pp. 240-252.

Danchin, P. G. (2007/2008) 'The Emergence and Structure of Religious Freedom in International Law Reconsidered', Journal of Law and Religion, 23 (2), pp. 455-534.

Dressler, M. and Mandair, A. (2011) Secularism and Religion-Making. New York: Oxford University Press.

Evans, C. (2006) 'The 'Islamic Scarf' in the European Court of Human Rights', Melbourne Journal of International Law, 7 (1), pp. 52-73.

Ferrari S. (2013) 'In Praise of Pragmatism', in Ferrari, A. and Pastorelli, S. The Burqa Affair Across Europe: Between Public and Private Space. Farnham; Burlington: Ashgate, pp. $5-14$.

Foblets, M.-C. and Alidadi, K. (eds.) (2013) Summary Report of the RELIGARE Project. Available at:

http://www.religareproject.eu/system/files/RELIGARE\%20Summary\%20Report_0.pdf

Fokas, E. (2015) 'Directions in Religious Pluralism in Europe: Mobilizations in the Shadow of European Court of Human Rights Religious Freedom Jurisprudence', Oxford Journal of Law and Religion, 4(1), pp. 54-74.

Habermas, J. (1987) The Theory of Communicative Action. Boston: Beacon Press.

Heelas, P. and Woodhead, L. (2005) The Spiritual Revolution: Why Religion is Giving Way to Spirituality. Oxford: Blackwell.

Hefner, R. W. (2015) 'Varieties of Religious Freedom and Governance: A Practical Perspective', in Sullivan, W. F. et al. Politics of Religious Freedom. Chicago; London: University of Chicago Press, pp. 127-134.

Hurd, E. S. (2015) Beyond Religious Freedom: The New Global Politics of Religion. Princeton; Oxford: Princeton University Press.

Ignatieff, M. (2003) Human Rights as Politics and Ideology. Edited and with an introduction by Amy Gutmann. Princeton: Princeton University Press.

Joas, H. (2016). 'Sacralization and Desacralization: Political Domination and Religious Interpretation', Journal of the Society of Christian Ethics, (2)36, pp. 25-42. 
Koskenniemi, M. (2001) 'Human rights, politics and love', Mennesker \& Rettigheter, 1(4), pp. 33-45.

Loick, D. (2014) 'Juridification and politics: From the dilemma of juridification to the paradoxes of rights', Philosophy and Social Criticism, 40(8), pp. 757-778.

Mahmood, S. (2016) Religious Difference in A Secular Age: A Minority Report. Princeton; Oxford: Princeton University Press.

Mahmood, S. (2012) 'Religious Freedom, the Minority Question, and Geopolitics in the Middle East', Comparative Studies in Society and History, 54 (2), pp. 418-446.

Modood, T. (2012) 'Is There a Crisis of Secularism in Western Europe?', Sociology of Religion, 73 (2), pp. 130-149.

Mäkinen, V. (ed.) (2006) Lutheran Reformation and the Law. Leiden: Brill Academic Publishers.

Peroni, L. (2014a) 'Deconstructing 'Legal' Religion in Strasbourg', Oxford Journal of Law and Religion, 3 (2), pp. 235-257.

Peroni, L. (2014b) 'Religion and Culture in the Discourse of the European Court of Human Rights: The Risks of Stereotyping and Naturalising', International Journal of Law in Context, 10 (2), pp. 195-221.

Pirková, E. (2015) 'The Categorization of Minorities in the European Context', in Gozdecka, D. and Kmak, M. (eds.) Europe at the Edge of Pluralism. Cambridge; Antwerp; Portland: Intersentia, pp. 43-57.

Research plan of the HERA-funded project "Protestant Legacies in Nordic Law: Uses of the Past in the Construction of the Secularity of Law". (2015) On file with the author.

Rosen, L. (2006) Law as Culture. Princeton (NJ): Princeton University Press.

Sandberg, R. (ed.) (2015) Religion and Legal Pluralism. Farnham; Burlington: Ashgate.

Sandberg, R. (2015) 'The Impossible Compromise', in Sandberg, R. (ed.) Religion and Legal Pluralism. Farnham; Burlington: Ashgate, pp. 1-17.

Sandberg, R. (2014) Religion, Law and Society. Cambridge: Cambridge University Press. Sandberg, R. (2011) Law and Religion. Cambridge: Cambridge University Press.

Schwarz Lausten, M. (2011) Reformationen i Danmark. Copenhagen: Anis. 
Slotte, P. (2013) 'Freedom of Religion, Freedom of Conscience and Education: A Nordic Example', in Durham, Jr., W. C. et al. (ed.) Law, Religion, Constitution: Freedom of Religion, Equal Treatment, and the Law. Farnham; Burlington: Ashgate, pp. 331-368.

Slotte, P. (2012 (2010)) 'The Religious and the Secular in European Human Rights Discourse', Finnish Yearbook of International Law, 21, pp. 231-286.

Slotte, P. (2010) 'On Law, Language and Human Embeddedness', in Christoffersen, L. et al. (ed.) Law and Religion in the 21st Century: Nordic Perspectives. Copenhagen: Djøf Publishing.

Sorsa, L. (2015) Kirkkona valtiossa: Katsaus Suomen evankelis-luterilaisen kirkon valtiosuhteen edellytyksiin ja uudistuspaineisiin. Kirkon tutkimuskeskuksen verkkojulkaisuja 41. Kirkon tutkimuskeskus. Available at: http://sakasti.evl.fi/julkaisut.nsf/097E1791EA9D20EBC2257E2E0012D577/\$FILE/verkkojul kaisu41.pdf

Spring, J. A. 'Tentacles of the Leviathan? Nationalism, Islamophobia, and the Insufficiency-yet-Indispensability of Human Rights for Religious Freedom in Contemporary Europe', Journal of the American Academy of Religion, pp. 1-34.

Sullivan, W. F. (2007) The Impossibility of Religious Freedom. Princeton: Princeton University Press.

Taylor, C. (2007) A Secular Age. Cambridge: The Belknap Press of Harvard University Press.

Tamm, D. (2005) Retshistorie: Danmark - Europa - globale perspektiver. 2nd edn. Copenhagen: Djøf.

Trispiotis, I. (2016) 'Two Interpretations of “Living together” in European Human Rights Law', Cambridge Law Journal 75 (3), pp. 580-607.

\footnotetext{
${ }^{1}$ This article was written as part of the author's personal Academy of Finland Academy Research Fellow project "Management of the Sacred - A Critical Inquiry" (2013-2018). It further in some instances draws on a few ideas from the international research project "Protestant Legacies in Nordic Law: Uses of the Past in the Construction of the Secularity of Law" (2016-2019), which during the time of writing was awarded funding from the Humanities in the European Research Area (HERA).
} 
${ }^{2}$ For a discussion of similar aspects, see e.g. Foblets and Alidadi, 2013, pp. 24-25. Part of the ideas presented in this article have also been elaborated in the essay 'Neutraaliudesta, normeista ja niqabeista', http://www.areiopagi.fi/2016/04/neutraaliudesta-normeista-ja-niqabeista/ (last visited 17.9.2016).

3 Loi interdisant la dissimulation du visage dans l'espace public, http://www.assembleenationale.fr/13/ta/ta0524.asp (last visited 2.5.2016). For a critical analysis of the aims of the legislation banning face veiling in France, and also in Belgium, see e.g. Brems et al. 2013. For a recent comprehensive discussion of the issue of veiling and legal responses to the practice, see Brems (ed.) 2014.

${ }^{4}$ The RELIGARE project, for example, singles out such cases related to gender equality and equal treatment of sexual minorities as "hard cases" where religious accommodation clashes with other fundamental rights (Foblets and Alidadi, 2013, p. 11). For a discussion, see also e.g. Alidadi, 2012, pp. 700-701.

${ }^{5}$ See also e.g. Alidadi, 2012, p. 711, who further refers to Bader 2007, p. 167; and Modood 2012, p. 136.

${ }^{6}$ Vocabulary borrowed from Berman, 2012, pp. 45-46. Sure enough, it can also go the other way around. In an article written before the case of Eweida and Others v. the United Kingdom (Application nos. 48420/10, 59842/10, 51671/10 and 36516/10, European Court of Human Rights, Judgment (15 January 2013), Katayoun Alidadi puts forward 'reasonable accommodation' as a way to deal with limitations shining through in the jurisprudence of the European Court of Human Rights (and earlier the European Commission of Human Rights), as far as recognising the need to accommodate religious beliefs and practices in the work space is concerned. Often enough in the past, the freedom to resign has been considered a sufficient safeguard for individuals who found it difficult to reconcile, for example, particular work tasks or working hours with their religious commitments (Alidadi 2012, pp. 702706).

${ }^{7}$ For similar observations, see e.g. Blichner and Molander, 2008, p. 37.

${ }^{8}$ For a thorough analysis of the various dimensions mentioned here, see e.g. Blichner and Molander, 2008, pp. 3654. As regards juridification of religion, see e.g. Sandberg, 2011, pp. 193-195, as well as more comprehensively Årsheim and Slotte 2017.

${ }^{9}$ See e.g. the cases of Dahlab v. Switzerland, Application no. 42393/98, European Court of Human Rights, inadmissibility decision (15 February 2001), ECHR 2001-V; Leyla Şahin v. Turkey, Application no. 44774/98, European Court of Human Rights, Grand Chamber Judgment (10 November 2005); Dogru v. France, Application no. 27058/05, European Court of Human Rights, Judgment (4 December 2008), and Kervanci v. France, Application no. 31645/04, European Court of Human Rights, Judgment (4 December 2008); S.A.S. v. France, Application no. 43835/11, European Court of Human Rights, Grand Chamber Judgment (1 July 2014); Ebrahimian v. France, Application no. 64846/11, European Court of Human Rights, Judgment (26 November 2015). For two efforts to articulate in an academic context (with links also to the earlier mentioned RELIGARE project), a 'pragmatic' and 'functional' approach on part of society and its law to the matter of full-face veiling, see Ferrari 2013 and Christoffersen 2013.

${ }^{10}$ For a critique, see e.g. Evans, 2006; Slotte, 2012 (2010); Bhuta, 2014; Peroni, 2014b; Fokas 2015; Trispiotis 2016.

${ }^{11}$ See e.g. Sullivan, 2007; Slotte, 2012 (2010); Bhuta, 2014; Peroni, 2014a; Årsheim, 2015; Danchin, 2015; Mahmood, 2016, pp. 167-180.

${ }^{12}$ In another context with regard to the 'family', rather than 'religion'. 
${ }^{13}$ See also Springs, 2016, p. 4. I am grateful to Helge Årsheim for drawing my attention to this article and its perspective of the matters at hand.

${ }^{14} \mathrm{Cf}$. an article where I analyse the ways in which religious education within the Finnish school system gives expression to particular views of religion and society (Slotte, 2013).

${ }^{15}$ See e.g. Slotte 2012 (2010); Mahmood, 2012, p. 429. I have, for example, elsewhere argued that within European human rights law as presently interpreted, practices regarded as 'religious' are accommodated by and subordinated to certain 'liberal-secular' assumptions about politics, law, statehood and citizenship (Slotte, 2012 (2010)). See also, e.g. Bhuta, 2014.

${ }^{16}$ For such studies, see e.g. Asad, 2003; Cavanaugh, 2009; Taylor, 2007, Danchin, 2007/2008; Slotte, 2012 (2010). Robert W. Hefner has made the important observation that: "There is a tendency among proponents and critics of liberal freedom alike to overintellectualize and homogenize the genealogy of religious freedom in the modern West. This simplification results in part from a tendency to conflate philosophical genealogies of religious freedom with a more comprehensive sociology of the real and existing varieties of ethicoreligious practice and governance." (Hefner, 2015, p. 128) We need to be aware of this risk of overlooking the intricacies of historical trajectories and struggles to affect religious governance; the actors with their diverse motives, the powers and discourses involved (Hefner, 2015, pp. 128-129). Still, while we can surely also find discontinuities - the histories of rights may be "multiple, discontinuous, and fragmentary" (Bhuta, 2014, p. 10), and I do not want to propose some form of teleology, put forward a "monofocal" "evolutionist" history (Dressler and Mandair, 2011, p. 20), or resort to “[g]enealogical determinism” (Springs, 2016, p. 7), historical notions do influence - for lack of a better word we could perhaps also talk of 'recurrences' - the conceptualization of religion in contemporary human rights discourse, and law more generally. The discourse carries a legacy.

17 The 'egalitarian imaginary' of human rights, for example, that is ostensibly neutral, 'non-political' and 'agnostic', when it comes to religion de facto privileges some believers over others.

${ }^{18}$ This can be related to the point made by Hans Joas in his contribution to this volume, namely that we must "make a sharp conceptual distinction between the sacred and religion—at least in the sense that we must eschew any tendency to derive the sacred from religions and instead view religions as attempts to interpret the experience of the sacred". Joas 2016, 27. They are not alone in this.

${ }^{19}$ And I guess, something similar is the case, for example, to the extent that Nordic legal institutions fail to acknowledge the way they are indebted to and building on particular religious' heritages.

${ }^{20}$ It is a task which, if Berman is to be believed, has not changed but perhaps even intensified. As Berman puts it: "Even more so than in the interwar period, we live in a world in which proponents of religion as a vehicle for stabilizing and sanctifying existing state and international legal orders compete with proponents of religion as a vehicle for destabilizing those orders - as well as one marked by fierce controversy about what kind of religious forces play which roles" (Berman, 2012, p. 13). See also e.g. Berman, 1995-1996, p. 830.

21 'Human dignity' is something often mentioned here as a thing held sacred. Michael Ignatieff has famously stated that some consider human rights 'sacred' and thus, these rights are "articles of faith" (Ignatieff, 2003, p. 53). See also e.g. Joas 2016, 37-38.

${ }^{22}$ For an insightful contribution that argues that 'human rights' and 'religious freedom' may still have a role to play in safeguarding individuals and groups, despite the criticism that scholars engaging in so-called deconstructive work has directed against this discourse as - among other things - a vehicle of state domination, 
see Springs, 2016. Springs argues that European human rights law allows for "alternative reading[s]" (Springs, 2016, p. 13) and "interpretative flexibility" (Springs, 2016, p. 14).

${ }^{23}$ As is pointed out in the Summary report of the RELIGARE project: "the symbolic meaning of the full-face veil ... varies from person to person ... and can never be ascertained with certainty" (Foblets and Alidadi, 2013, p. 25).

${ }^{24}$ However, see also Alidadi, 2012, for a thorough account of the multiple ways in which 'reasonable accommodation' could be helpful and hold appeal not simply in a strictly legal sense, helping to counter some of the drawbacks of a human rights and a non-discrimiation law framework. In the article, Alidadi also evaluates the merits of the idea of 'deep equality' that Beaman puts forward as an alternative to reasonable accommodation. 